\title{
Atrial fibrillation: risk factors and comorbidities in a tertiary center in Jeddah, Saudi Arabia
}

This article was published in the following Dove Medical Press journal: International Journal of General Medicine

\section{Abdullah Abdulfattah Mashat \\ Ahmed Hussein Subki Moaz Abdulrahman \\ Bakhaider \\ Wejdan Mohammad \\ Baabdullah \\ Jawaher Badr Walid \\ Abdulrahman Hatim \\ Alobudi \\ Maged Mazen Fakeeh \\ Anas Jamal Algethmi \\ Wesam Awad Alhejily}

Department of Internal Medicine, College of Medicine, King Abdulaziz University, Jeddah, Saudi Arabia
Correspondence: Wesam Awad Alhejily Department of Internal Medicine, College of Medicine, King Abdulaziz University, PO Box 43I29, Jeddah 2156I, Saudi Arabia

Tel +966546033322

Email walhejily@kau.edu.sa
Introduction: Atrial fibrillation (AF) is the most common type of cardiac arrhythmia worldwide and carries significant risk of morbidity and mortality. The prevalence of AF is high in significant parts of the world, but not much is known from countries, such as Saudi Arabia.

Aims: To study the risk factors, etiologies, comorbidities, and outcome of AF in Saudi Arabia. Patients and methods: A retrospective study was conducted in King Abdul-Aziz Hospital in Jeddah during the period 2010-2017. Data were collected from both the electronic-and paperbased medical records of patients with AF. The data included the demographic information, adverse lifestyle (smoking and obesity), cardiothoracic surgery, and comorbidities.

Results: A total of 167 patients were included in the analysis ( $43 \%$ were males). The mean age was $63.3 \pm 35$ years and the mean body mass index was $28.8 \pm 83$. Hypertension (HTN) was the most prevalent risk factor encountered (73.1\%). This was followed by valvular heart disease, and type 2 diabetes mellitus (T2DM), which occurred in $58.7 \%$ and $53.3 \%$ of patients, respectively. Valvular heart disease was significantly associated with older age $(P=0.002)$ and coronary artery disease $(\mathrm{CAD})(P=0.001)$. Heart failure (HF) was associated with HTN $(P=0.005)$, coronary heart disease $(P=0.001)$, and chronic kidney disease $(\mathrm{CKD})(P=0.003)$.

Conclusion: AF was more prevalent among females in Saudi Arabia. HTN, valvular heart disease, and T2DM were the most prevalent risk factors of AF in Saudi Arabia. Valvular heart disease was more prevalent among older patients and significantly associated with CAD. HTN, $\mathrm{CAD}$, and CKD were the most significant risk factors for HF in patients with AF.

Keywords: atrial fibrillation, comorbidities, complications, risk factors, Jeddah, Saudi Arabia

\section{Introduction}

Atrial fibrillation (AF) is the most common type of arrhythmia worldwide. It is the result of structural and/or electrophysiological abnormalities that produce abnormal impulse formation. An estimated 33.5 million individuals had AF by the year $2010{ }^{1}$ While more epidemiological studies on AF were carried out in developed countries, the rate of prevalence and incidence is steadily increasing worldwide. The prevalence in the USA, Europe, and New Zealand was 2.3\%, 2\%, and 1.7\%, respectively. ${ }^{2-4}$ In Saudi Arabia, only two hospital-based studies showed dissimilarities in the main causes of AF, whereas it has been attributed to the increasing aging population in the West. ${ }^{5,6}$ The implications of AF represent a great burden in terms of morbidity and mortality due to thromboembolic complications and heart failure (HF) as well as a wider healthcare and economic burden. ${ }^{1} \mathrm{AF}$ is a multifactorial condition. The risks of developing AF can be associated with demographic factors, lifestyle factors, cardiovascular conditions, 
and comorbid conditions/procedures. ${ }^{7}$ The prevalence of AF increases with age; $\sim 70 \%$ of cases of AF are in patients between 65 and 85 years of age. ${ }^{8}$ Male gender is associated with a 1.5 -fold increased risk of developing AF. ${ }^{9}$ Risk of AF is also increased with low socioeconomic status. ${ }^{10}$ Alcohol consumers and current or former smokers are at greater risk of developing AF, ${ }^{11,12}$ and obesity (body mass index [BMI] $\geq 30 \mathrm{~kg} / \mathrm{m}^{2}$ ) and high BMI are also associated with $\mathrm{AF}^{7}$ In Saudi Arabia, hypertension (HTN) and diabetes are the most common risk factors for $\mathrm{AF}^{6}$ Valvular heart disease, especially mitral valve disease, is another risk factor for AF observed particularly in developing countries. ${ }^{13}$ The likelihood of AF increases with structural heart disease. It is estimated that $>70 \%$ of patients with AF have cardiac disease, such as ischemic heart disease, myocarditis, pericarditis, cardiomyopathy, and hypertensive heart disease; congestive $\mathrm{HF}$ as AF is found in $30 \%-40 \%$ of patients with HF. ${ }^{13,14}$ Other comorbid diseases included are as follows: obstructive sleep apnea (OSA), chronic kidney disease (CKD), and pulmonary disease. ${ }^{7}$ Thyroid dysfunction, especially hyperthyroidism, has also been linked to AF. ${ }^{15}$

By identifying the common risk factors and etiologies of AF related to the community, it will be possible to better detect and screen high-risk populations to prevent future complications of AF, such as stroke and thromboembolic attacks. Thus, this research aims to study the general characteristics of AF patients at King Abdulaziz University Hospital (KAUH), Jeddah, Saudi Arabia and identify the common comorbidities and risk factors associated with these patients. Moreover, the study aims to examine how AF patients who have valvular heart disease, HF, or diabetes mellitus (DM) differ from those who do not.

\section{Patients and methods}

In reporting the methods of the study, the Strengthening the Reporting of Observational Studies in Epidemiology guidelines were followed.

\section{Study design}

A retrospective study was conducted to assess the common risk factors and their prevalence in patients diagnosed with AF.

\section{Setting}

The study was conducted in KAUH from 2010 to 2017. KAUH is a teaching tertiary center located in Jeddah, Saudi Arabia.

\section{Participants}

A total of 167 patients were included in the study, representing all patients diagnosed with AF from 2010 to 2017 in KAUH. The diagnosis of AF was based on electrocardiogram findings and cardiologist experience.

\section{Data sources and variables}

Data were collected by utilizing both electronic - and paperbased medical records of patients diagnosed with AF. Information obtained from the medical records was collected on a structured form that included: demographic information, adverse lifestyle (smoking and obesity), and comorbidities. Patients' comorbidities included: HTN, ischemic heart disease, valvular heart disease, rheumatic heart disease, type 2 (T2DM), hyperthyroidism, OSA, CKD, rheumatoid arthritis (RA), and HF.

\section{Bias}

In order to minimize selection bias, all patients diagnosed with AF in the time period of the study were included.

\section{Statistical methods}

Categorical variables were presented as frequencies and percentages. Continuous variables were presented as the mean \pm SD. Patients were divided according to the presence and absence of valvular disease, HF, and T2DM. Comparison of these groups was carried out using the chi-squared test (for categorical variables) and independent samples $t$-test (for continuous variables). The level of significance was presented as $P$-values in different tables. All the required data for the current study were carefully collected, which resulted in no missing data, hence, missing data management was not required. The analysis was performed at a 5\% level of significance using the SPSS, version 23 (IBM, Armonk, NY, USA). Data analysis was performed using SPSS, version 21 (SPSS Inc., Chicago, IL, USA). All $P$-values $<0.05$ are considered statistically significant.

\section{Ethical approval}

This study was approved by the Unit of Biomedical Ethics Research Committee at King Abdulaziz University, and it was conducted in accordance with the Declaration of Helsinki. Patient consent to review their medical records was not required by the ethics committee. This waiver was due to the retrospective chart review nature of our study. No personal data that could reveal a patient entity were used. Patient data were strictly protected for confidentiality when conducting this study. 


\section{Results}

A total of 167 patients with AF were included in this study, of whom $72(43.1 \%)$ were males. The mean \pm SD age and BMI of all patients were $63.35 \pm 16.07$ years and $28.83 \pm 7.67$ $\mathrm{kg} / \mathrm{m}^{2}$, respectively. More than half $(58.7 \%)$ of the patients were non-Saudi nationals (Table 1). The most prevalent risk factor among all patients was systemic HTN, present in $73.1 \%$, followed by valvular disease $(58.7 \%)$ and T2DM (53.3\%). OSA (2.4\%) and RA (3.0\%) were among the least prevalent medical conditions.

Table I Baseline characteristics of all patients $(n=167)$

\begin{tabular}{|l|l|}
\hline Characteristics & N (\%) \\
\hline Age (years) (mean \pm SD) & $63.35 \pm 16.07$ \\
Gender & \\
Male & $72(43.1)$ \\
Female & $95(56.9)$ \\
Nationality & \\
Saudi & $69(41.3)$ \\
Non-Saudi & $98(58.7)$ \\
BMI $\left(\mathrm{kg} / \mathrm{m}^{2}\right)($ mean \pm SD) & $28.83 \pm 7.67$ \\
\hline
\end{tabular}

Abbreviation: BMI, body mass index.
The mean age difference between valvular $(66.50 \pm 14.49$ years) and nonvalvular ( $58.87 \pm 17.20$ years) heart disease patients was statistically significant $(P=0.002)$. The study also identified that coronary artery disease (CAD) was statistically more prevalent among valvular disease patients compared with their counterparts $(P=0.001)$. Comparison of other variables of interest between valvular vs nonvalvular disease patients was statistically insignificant (Table 2).

All the AF patients were split and compared according to the presence or absence of HF. Systemic HTN $(P=0.005)$, $\mathrm{CAD}(P<0.001)$, and $\mathrm{CKD}(P=0.003)$ were significantly more prevalent among the patients with HF compared with the rest of the patients. Comparison between all other characteristics was not statistically significant (Table 3 ).

Because of the notable high prevalence of DM among the studied samples, the patients were compared according to presence or absence of T2DM. The results revealed the mean \pm SD age of the former patients $(69.25 \pm 12.66$ years $)$ was significantly greater than the mean $\pm \mathrm{SD}$ age of the latter patients $(56.62 \pm 16.95$ years $)(P<0.001)$. A higher percentage of male AF patients had insulin-dependent DM compared with females $(P=0.009)$. T2DM patients also had a higher

Table 2 Comparison of baseline characteristics, medical conditions, and cardiac risk factors between patients having valvular disease and not having valvular disease $(n=167)$

\begin{tabular}{|c|c|c|c|c|}
\hline Characteristics & Attributes & Yes N (\%) $(n=98)$ & No $N(\%)(n=69)$ & $P$-value \\
\hline $\begin{array}{l}\text { Age (years) } \\
(\text { mean } \pm \text { SD) }\end{array}$ & & $66.50 \pm 14.49$ & $58.87 \pm 17.20$ & 0.002 \\
\hline Gender & $\begin{array}{l}\text { Male } \\
\text { Female }\end{array}$ & $\begin{array}{l}39(39.8) \\
59(60.2)\end{array}$ & $\begin{array}{l}33(47.8) \\
36(52.2)\end{array}$ & .302 \\
\hline Nationality & $\begin{array}{l}\text { Saudi } \\
\text { Non-Saudi }\end{array}$ & $\begin{array}{l}34(34.7) \\
64(65.3)\end{array}$ & $\begin{array}{l}35(50.7) \\
34(49.3)\end{array}$ & 0.038 \\
\hline $\begin{array}{l}\mathrm{BMI}\left(\mathrm{kg} / \mathrm{m}^{2}\right) \\
(\text { mean } \pm \mathrm{SD})\end{array}$ & & $28.6 \mathrm{I} \pm 8.02$ & $29.14 \pm 7.23$ & 0.672 \\
\hline Smoking & $\begin{array}{l}\text { Yes } \\
\text { No }\end{array}$ & $\begin{array}{l}\text { II (II I.2) } \\
87(88.8)\end{array}$ & $\begin{array}{l}7(10.1) \\
62(89.9)\end{array}$ & 0.825 \\
\hline HTN & $\begin{array}{l}\text { Yes } \\
\text { No }\end{array}$ & $\begin{array}{l}75(76.5) \\
23(23.5)\end{array}$ & $\begin{array}{l}47(68.1) \\
22(31.9)\end{array}$ & 0.227 \\
\hline CAD & $\begin{array}{l}\text { Yes } \\
\text { No }\end{array}$ & $\begin{array}{l}52(53.1) \\
46(46.9)\end{array}$ & $\begin{array}{l}\text { I8 (26.I) } \\
5 \text { I (73.9) }\end{array}$ & 0.001 \\
\hline RHD & $\begin{array}{l}\text { Yes } \\
\text { No }\end{array}$ & $\begin{array}{l}6(6.1) \\
92(93.9)\end{array}$ & $\begin{array}{l}2(2.9) \\
67(97.1)\end{array}$ & 0.337 \\
\hline T2DM & $\begin{array}{l}\text { Yes } \\
\text { No }\end{array}$ & $\begin{array}{l}54(55.1) \\
44(44.9)\end{array}$ & $\begin{array}{l}35(50.7) \\
34(49.3)\end{array}$ & 0.312 \\
\hline Hyperthyroidism & $\begin{array}{l}\text { Yes } \\
\text { No }\end{array}$ & $\begin{array}{l}3(3.1) \\
95(96.9)\end{array}$ & $\begin{array}{l}5(7.2) \\
64(92.8)\end{array}$ & 0.212 \\
\hline OSA & $\begin{array}{l}\text { Yes } \\
\text { No }\end{array}$ & $\begin{array}{l}2(2.0) \\
96(98.0)\end{array}$ & $\begin{array}{l}2(2.9) \\
67(97.1)\end{array}$ & 0.721 \\
\hline CKD & $\begin{array}{l}\text { Yes } \\
\text { No }\end{array}$ & $\begin{array}{l}19(19.4) \\
79(80.6)\end{array}$ & $\begin{array}{l}6(8.7) \\
63(91.3)\end{array}$ & 0.057 \\
\hline RA & $\begin{array}{l}\text { Yes } \\
\text { No }\end{array}$ & $\begin{array}{l}2(2.0) \\
96(98.0)\end{array}$ & $\begin{array}{l}3(4.3) \\
66(95.7)\end{array}$ & 0.067 \\
\hline
\end{tabular}

Abbreviations: BMI, body mass index; HTN, hypertension; CAD, coronary artery disease; HTN, hypertension; T2DM, type 2 diabetes mellitus; RA, rheumatoid arthritis; RHD, rheumatic heart disease; CKD, chronic kidney disease; OSA, obstructive sleep apnea. 
Table 3 Comparison of baseline characteristics, medical conditions, and cardiac risk factors between patients with heart failure and with no heart failure $(n=167)$

\begin{tabular}{|c|c|c|c|c|}
\hline Characteristics & Attributes & $\begin{array}{l}\text { Yes N (\%) } \\
(n=62)\end{array}$ & $\begin{array}{l}\text { No N (\%) } \\
(n=105)\end{array}$ & $P$-value \\
\hline $\begin{array}{l}\text { Age (years) } \\
(\text { mean } \pm S D)\end{array}$ & & $66.50 \pm 13.30$ & $61.49 \pm 17.29$ & 0.051 \\
\hline Gender & $\begin{array}{l}\text { Male } \\
\text { Female }\end{array}$ & $\begin{array}{l}32(51.6) \\
30(48.4)\end{array}$ & $\begin{array}{l}40 \text { (38.1) } \\
65 \text { (61.9) }\end{array}$ & 0.088 \\
\hline Nationality & $\begin{array}{l}\text { Saudi } \\
\text { Non-Saudi }\end{array}$ & $\begin{array}{l}21 \text { (33.9) } \\
4 \mid(66 . I)\end{array}$ & $\begin{array}{l}48(45.7) \\
57(54.3)\end{array}$ & 0.133 \\
\hline $\begin{array}{l}\mathrm{BMI}\left(\mathrm{kg} / \mathrm{m}^{2}\right) \\
(\text { mean } \pm \mathrm{SD})\end{array}$ & & $28.84 \pm 6.63$ & $28.83 \pm 8.30$ & 0.995 \\
\hline Valvular disease & $\begin{array}{l}\text { Yes } \\
\text { No }\end{array}$ & $\begin{array}{l}4 I \text { (66.I) } \\
21 \text { (33.9) }\end{array}$ & $\begin{array}{l}57(54.3) \\
48(45.7)\end{array}$ & 0.133 \\
\hline Smoking & $\begin{array}{l}\text { Yes } \\
\text { No }\end{array}$ & $\begin{array}{l}10(16.1) \\
52(83.9)\end{array}$ & $\begin{array}{l}8(7.6) \\
97(92.4)\end{array}$ & 0.087 \\
\hline HTN & $\begin{array}{l}\text { Yes } \\
\text { No }\end{array}$ & $\begin{array}{l}53(85.5) \\
9(14.5)\end{array}$ & $\begin{array}{ll}69 & (65.7) \\
36 & (34.3)\end{array}$ & 0.005 \\
\hline CAD & $\begin{array}{l}\text { Yes } \\
\text { No }\end{array}$ & $\begin{array}{l}37(59.7) \\
25(40.3)\end{array}$ & $\begin{array}{l}33(31.4) \\
72(68.6)\end{array}$ & $<0.001$ \\
\hline RHD & $\begin{array}{l}\text { Yes } \\
\text { No }\end{array}$ & $\begin{array}{l}3(4.8) \\
59(95.2)\end{array}$ & $\begin{array}{l}5(4.8) \\
100(95.2)\end{array}$ & 0.982 \\
\hline T2DM & $\begin{array}{l}\text { Yes } \\
\text { No }\end{array}$ & $\begin{array}{l}37(59.7) \\
25(40.3)\end{array}$ & $\begin{array}{l}52(49.5) \\
53(50.5)\end{array}$ & 0.204 \\
\hline Hyperthyroidism & $\begin{array}{l}\text { Yes } \\
\text { No }\end{array}$ & $\begin{array}{l}4(6.5) \\
58(93.5)\end{array}$ & $\begin{array}{l}4(3.8) \\
101(96.2)\end{array}$ & 0.440 \\
\hline OSA & $\begin{array}{l}\text { Yes } \\
\text { No }\end{array}$ & $\begin{array}{l}3(4.8) \\
59(95.2)\end{array}$ & $\begin{array}{l}\text { I (I.0) } \\
\text { I04 (99.0) }\end{array}$ & 0.113 \\
\hline CKD & $\begin{array}{l}\text { Yes } \\
\text { No }\end{array}$ & $\begin{array}{l}16(25.8) \\
46(74.2)\end{array}$ & $\begin{array}{l}9(8.6) \\
96(91.4)\end{array}$ & 0.003 \\
\hline RA & $\begin{array}{l}\text { Yes } \\
\text { No }\end{array}$ & $\begin{array}{l}\text { I (1.6) } \\
61(98.4)\end{array}$ & $\begin{array}{l}4(3.8) \\
101(96.2)\end{array}$ & 0.421 \\
\hline
\end{tabular}

Abbreviations: BMI, body mass index; HTN, hypertension; CAD, coronary artery disease; HTN, hypertension; T2DM, type 2 diabetes mellitus; RA, rheumatoid arthritis; RHD, rheumatic heart disease; CKD, chronic kidney disease; OSA, obstructive sleep apnea.

chance of having $\operatorname{HTN}(P<0.001)$ and $\mathrm{CAD}(P<0.001)$ compared with patients with no T2DM (Table 4).

\section{Discussion}

In the present study, 167 patients with $\mathrm{AF}$ were recruited over a 7 -year period based on the medical records of KAUH in Jeddah, Saudi Arabia. The mean age of the studied patients (63.35 years) matched the common age of developing AF identified in the literature. AF is common in the elderly population and is rare in $<50$ years of age. ${ }^{16}$ Many mechanisms have been postulated for the correlation between the pathophysiology of aging and the development of AF. Some authors have hypothesized that the electrophysiological changes and the elevated resting membrane potential are the main pathophysiological mechanisms driving the abnormal intracellular calcium handling and the subsequent development of arrhythmia. ${ }^{17}$ Others have attributed the high prevalence of AF among the elderly to the reduction in atrial remodeling and the activation of oxidative cellular damage with the accumulation of ROS. ${ }^{18}$ The mean BMI of the studied patients in this research was 28.83. In agreement with previous research, obesity appears to be a risk factor for $\mathrm{AF}$ is Saudi Arabia. ${ }^{15,19}$ Obesity was reported to have negative consequences on cardiac structure, circulatory hemodynamics, and myocardial remodeling leading to a higher prevalence of AF among obese patients..$^{20}$ In agreement with our results, Balaghi-Inalou et al, in their cross-sectional study on 120 patients with AF from Iran, reported that AF was common among elderly patients aged $>60$ years. ${ }^{21}$

With regard to gender, the results of the present study differed slightly from the literature. While AF is often reported to be prevalent among males, more than half of the recruited patients in this study were female. ${ }^{22}$ However, the present study had a higher number of patients with valvular than with nonvalvular heart disease; and, when the gender difference among AF patients with valvular and nonvalvular heart disease was compared, it was found that females were more likely to have AF with valvular heart disease, whereas 
Table 4 Comparison of baseline characteristics, medical conditions, and cardiac risk factors between patients with T2DM and with no T2DM (n=167)

\begin{tabular}{|c|c|c|c|c|}
\hline Characteristics & Attributes & $\begin{array}{l}\text { Yes N (\%) } \\
(n=89)\end{array}$ & $\begin{array}{l}\text { No N (\%) } \\
(n=78)\end{array}$ & $P$-value \\
\hline $\begin{array}{l}\text { Age (years) } \\
(\text { mean } \pm \text { SD) }\end{array}$ & & $69.25 \pm 12.66$ & $56.62 \pm 16.95$ & $<0.001$ \\
\hline Gender & $\begin{array}{l}\text { Male } \\
\text { Female }\end{array}$ & $\begin{array}{l}30(33.7) \\
59(66.3)\end{array}$ & $\begin{array}{l}42(53.8) \\
36(46.2)\end{array}$ & 0.009 \\
\hline Nationality & $\begin{array}{l}\text { Saudi } \\
\text { Non-Saudi }\end{array}$ & $\begin{array}{l}34(38.2) \\
55(61.8)\end{array}$ & $\begin{array}{l}35 \text { (44.9) } \\
43(55.1)\end{array}$ & 0.383 \\
\hline $\begin{array}{l}\mathrm{BMI}\left(\mathrm{kg} / \mathrm{m}^{2}\right) \\
(\mathrm{mean} \pm \mathrm{SD})\end{array}$ & & $29.62 \pm 7.29$ & $27.92 \pm 8.05$ & 0.169 \\
\hline Valvular disease & $\begin{array}{l}\text { Yes } \\
\text { No }\end{array}$ & $\begin{array}{l}54(60.7) \\
35(39.3)\end{array}$ & $\begin{array}{l}44(56.4) \\
34(43.6)\end{array}$ & 0.577 \\
\hline Smoking & $\begin{array}{l}\text { Yes } \\
\text { No }\end{array}$ & $\begin{array}{l}10(11.2) \\
79(88.8)\end{array}$ & $\begin{array}{l}8(10.3) \\
70(89.7)\end{array}$ & 0.839 \\
\hline HTN & $\begin{array}{l}\text { Yes } \\
\text { No }\end{array}$ & $\begin{array}{l}76(85.4) \\
13(14.6)\end{array}$ & $\begin{array}{l}46(59.0) \\
32(41.0)\end{array}$ & $<0.001$ \\
\hline CAD & $\begin{array}{l}\text { Yes } \\
\text { No }\end{array}$ & $\begin{array}{l}50(56.2) \\
39(43.8)\end{array}$ & \begin{tabular}{|l}
$20(25.6)$ \\
$58(74.4)$
\end{tabular} & $<0.001$ \\
\hline RHD & $\begin{array}{l}\text { Yes } \\
\text { No }\end{array}$ & $\begin{array}{l}3(3.4) \\
86(96.6)\end{array}$ & $\begin{array}{l}5(6.4) \\
73(93.6)\end{array}$ & 0.359 \\
\hline Hyperthyroidism & $\begin{array}{l}\text { Yes } \\
\text { No }\end{array}$ & $\begin{array}{l}5(5.6) \\
84(94.4)\end{array}$ & $\begin{array}{l}3(3.8) \\
75(96.2)\end{array}$ & 0.593 \\
\hline OSA & $\begin{array}{l}\text { Yes } \\
\text { No }\end{array}$ & $\begin{array}{l}3(3.4) \\
86(96.6)\end{array}$ & $\begin{array}{l}\text { I (1.3) } \\
77 \text { (98.7) }\end{array}$ & 0.378 \\
\hline CKD & $\begin{array}{l}\text { Yes } \\
\text { No }\end{array}$ & $\begin{array}{l}16(18.0) \\
73(82.0)\end{array}$ & $\begin{array}{l}9 \text { (II.5) } \\
69(88.5)\end{array}$ & 0.245 \\
\hline RA & $\begin{array}{l}\text { Yes } \\
\text { No }\end{array}$ & $\begin{array}{l}3(3.4) \\
86(96.6)\end{array}$ & $\begin{array}{l}2(2.6) \\
76(97.4)\end{array}$ & 0.760 \\
\hline Heart failure & $\begin{array}{l}\text { Yes } \\
\text { No }\end{array}$ & $\begin{array}{l}37(41.6) \\
52(58.4)\end{array}$ & $\begin{array}{l}25(32.1) \\
53(67.9)\end{array}$ & 0.204 \\
\hline
\end{tabular}

Abbreviations: BMI, body mass index; HTN, hypertension; CAD, coronary artery disease; HTN, hypertension; T2DM, type 2 diabetes mellitus; RA, rheumatoid arthritis; RHD, rheumatic heart disease; CKD, chronic kidney disease; OSA, obstructive sleep apnea.

both genders had a similar risk of developing AF with nonvalvular heart diseases. These different characteristics may be the reason for the different results. Gender is known to be associated with significant differences among patients with $\mathrm{AF}^{23}$ Hormonal factors were proposed to play a major role; and the estrogen-progesterone fluctuation throughout the menstrual cycle was shown to have an impact on QT intervals. Females with AF have been reported to have more complications (especially cerebrovascular stroke and bleeding risk) and poorer outcomes than males. ${ }^{24,25}$ In the present study, female gender was significantly associated with DM on regression analysis compared with males $(\mathrm{OR}=0.4$, $P=0.009)$. No difference between the two genders was found with regard to HF risk $(P=0.088)$. In agreement with these results, a review by Ko et $\mathrm{al}^{26}$ reported that $\mathrm{HF}$ rates were not significantly different between males and females with $\mathrm{AF}$. However, the reverse was reported by O'Neal et al; ${ }^{27}$ in their research, females with $\mathrm{AF}$ had higher rates of hospitalization due to HF than males with the disease.
Upon reviewing the risk factors for AF in $\mathrm{KAUH}$, it was found that HTN was the most prevalent risk factor encountered in approximately three quarters of the recruited patients $(73.1 \%)$. The next most prevalent risk factors were valvular heart disease and T2DM, each occurring in more than half of the patients. Coronary heart disease, CKD, and smoking were less common, and few patients had RA, or OSA. HTN is a well-established risk factor for AF. It is estimated that one in every six cases of AF is caused by HTN. ${ }^{28}$ The mechanisms by which HTN can increase the risk of AF include left ventricular hypertrophy, diastolic dysfunction, and arterial atherosclerosis, which subsequently lead to atrial fibrosis and arrhythmia development. ${ }^{29}$ Furthermore, HTN increases the likelihood of other risk factors of AF, such as coronary heart disease, HF, and CKD. ${ }^{30}$ In the present study, regression analysis showed that HTN was significantly correlated with HF and DM. HTN not only causes AF, but also increases the risk of AF complications, particularly HF and embolic cerebrovascular stroke. ${ }^{31}$ In 
this study, hypertensive patients with AF were at three times more risk of developing HF than nonhypertensive patients $(P<0.005)$ and four times more likely to have comorbid T2DM $(P<0.001)$. Closely similar to our findings were the results reported by Balaghi-Inalou et al in Iran where HTN, congestive HF, and DM were prevalent among $78.3 \%$, $38.8 \%$, and $36.7 \%$, respectively. ${ }^{21}$

Valvular heart disease was more prevalent among patients with AF at KAUH than nonvalvular heart disease. Furthermore, valvular heart disease was significantly associated with old age and chronic heart disease when compared with nonvalvular disease. Patients with valvular heart disease tended to be 7 years older than patients with nonvalvular heart disease (66.5 vs 58.8 years). This is similar to what is reported in the literature: that valvular heart disease becomes more symptomatic and more severe with advanced age, with the highest prevalence in $>80$ years of age. ${ }^{32}$ Higher prevalence of valvular heart disease among females may be related to the higher rheumatic and autoimmune etiologies of valvular heart disease, which are more common among females; in addition, coronary heart disease is a common risk factor and complication of $\mathrm{AF}^{33,34}$

$\mathrm{HF}$ is not an uncommon complication of AF. The present study investigated the risk factors for HF among the studied patients with AF; CKD, coronary heart disease, and HTN were the only significantly correlated variables. CKD was found to be the greatest risk factor for HF. CKD was more prevalent among patients with AF and HF than in patients with AF and no HF. The correlation between CKD and HF have long been studied. Both conditions have similar risk factors and their co-occurrence is reported to be associated with poor outcome. ${ }^{35} \mathrm{HF}$ leads to accelerated atherosclerosis and reduction of blood flow to the kidney, leading to progressive damage to renal parenchyma and, consequently, CKD. ${ }^{36} \mathrm{CAD}$ was the second most powerful variable associated with $\mathrm{HF}$ $(P<0.001)$. HF increased the risk of coronary heart disease in the studied patients most likely via similar mechanisms of reduced blood flow and accelerated atherosclerosis. ${ }^{37}$ There was also a significant association between HTN and HF among the studied patients $(P=0.05)$. HTN results in progressive thickening of the left ventricle to compensate for the elevated pressure. Over time, the compensatory mechanisms fail and a transition from left ventricular hypertrophy to left ventricular dilatation and failure takes place. ${ }^{30}$

The present study has the advantage that the data used were collected from 7 years worth of patients in a tertiary center that accepts patients of different nationalities. Data were collected utilizing the hospital's electronic system, which resulted in no missing data. The main limitation of the present study is that the electronic system was introduced in the hospital in 2010, so data from before that time were not readily available. In addition, this study did not include data about the different types of AF and how they behave differently, due to lack of relevant documentation.

\section{Acknowledgments}

The authors thank Rayan Mohammed Bakhreba, Khalid Mohammed Nassibi, Jehad Jamil T Qashqari, Abdullah Marzouq MAlharbi, Khalid Waleed Kattan, Abdulrahman Mousa Alzahrani, Yahya Ali Alzahrani, Bader Khalid Alsheikh, Majd Mohammed Jamjoom, Ahmed Salem Alsulaimani, and Basim Ali Althinayyan for their help with data collection.

\section{Disclosure}

The authors report no conflicts of interest in this work.

\section{References}

1. Chugh SS, Havmoeller R, Narayanan K, et al. Worldwide epidemiology of atrial fibrillation: a global burden of disease 2010 study. Circulation. 2014;129(8):837-847.

2. AHA centers for Health Metrics and Evaluation. Projections of cardiovascular disease prevalence and costs: 2015-2035 (2017): health metrics. Available from: https://healthmetrics.heart.org/projections-ofcardiovascular-disease/. Accessed August 24, 2018.

3. Zoni-Berisso M, Lercari F, Carazza T, Domenicucci S. Epidemiology of atrial fibrillation: European perspective. Clin Epidemiol. 2014;6:213.

4. Tomlin AM, Lloyd HS, Tilyard MW. Atrial fibrillation in New Zealand primary care: prevalence, risk factors for stroke and the management of thromboembolic risk. Eur J Prev Cardiol. 2017;24(3):311-319.

5. Shatoor AS, Ahmed ME, Said MA, Shabbir K, Cheema A, Kardash MO. Patterns of atrial fibrillation at a regional hospital in Saudi Arabia. Ethn Dis. 1998;8(3):360-366. http://www.ncbi.nlm.nih.gov/ pubmed/9926906.

6. Bin Salih SA, Showlag MS, Al-Qahtani MA, Taha A, Yousuf M, Abdullah M. Clinical characteristics of patients with atrial fibrillation at a tertiary care hospital in the central region of Saudi Arabia. J Family Community Med. 2011;18(2):80.

7. Ball J, Carrington MJ, Mcmurray JJ V, Stewart S. Atrial fibrillation: profile and burden of an evolving epidemic in the 21 st century. Int $J$ Cardiol. 2013;167(5):1807-1824.

8. Feinberg WM, Blackshear JL, Laupacis A, Kronmal R, Hart RG. Prevalence, age distribution, and gender of patients with atrial fibrillation. Analysis and implications. Arch Intern Med. 1995;155(5):469-473.

9. Miyasaka Y, Barnes ME, Gersh BJ, et al. Secular trends in incidence of atrial fibrillation in Olmsted county, Minnesota, 1980 to 2000, and implications on the projections for future prevalence. Circulation. 2006;114(2):119-125.

10. Mattioli AV, Bonatti S, Zennaro M, Mattioli G. The relationship between personality, socio-economic factors, acute life stress and the development, spontaneous conversion and recurrences of acute lone atrial fibrillation. Europace. 2005;7(3):211-220.

11. Djoussé L, Levy D, Benjamin EJ, et al. Long-term alcohol consumption and the risk of atrial fibrillation in the Framingham study. Am J Cardiol. 2004;93(6):710-713.

12. Chamberlain AM, Agarwal SK, Folsom AR, et al. Smoking and incidence of atrial fibrillation: results from the Atherosclerosis Risk in Communities (ARIC) study. Heart Rhythm. 2011;8(8):1160-1166. 
13. Hersi A, Abdul-Moneim M, Almous'ad A, Al-Samadi F, Alfagih A, Sweidan R. Saudi atrial fibrillation survey: national, observational, cross-sectional survey evaluating atrial fibrillation management and the cardiovascular risk profile of patients with atrial fibrillation. Angiology. 2015;66(3):244-248.

14. Wyse DG, van Gelder IC, Ellinor PT, et al. Lone atrial fibrillation: does it exist? J Am Coll Cardiol. 2014;63(17):1715-1723.

15. Nieuwlaat R, Capucci A, Camm AJ. Atrial fibrillation management: a prospective survey in ESC member countries: the Euro Heart Survey on Atrial Fibrillation. Eur Heart J. 2005;26(22):2422-2434.

16. Reddy V, Taha W, Kundumadam S, Khan M. Atrial fibrillation and hyperthyroidism: a literature review. Indian Heart J. 2017;69(4):545-550.

17. Wongcharoen W, Chen YC, Chen YJ, et al. Aging increases pulmonary veins arrhythmogenesis and susceptibility to calcium regulation agents. Heart Rhythm. 2007;4(10):1338-1349.

18. Schillinger KJ, Patel VV. Atrial fibrillation in the elderly: the potential contribution of reactive oxygen species. J Geriatr Cardiol. 2012;9(4): 379-388.

19. Kozlowski D, Budrejko S, Lip GY, et al. Lone atrial fibrillation: what do we know? Heart. 2010;96(7):498-503.

20. Goudis CA, Korantzopoulos P, Ntalas IV, Kallergis EM, Ketikoglou DG. Obesity and atrial fibrillation: a comprehensive review of the pathophysiological mechanisms and links. J Cardiol. 2015;66(5):361-369.

21. Balaghi-Inalou M, Parsa SA, Gachkar L, Andalib S. Anticoagulant therapy in atrial fibrillation for stroke prevention: assessment of agreement between clinicians' decision and CHA2DS2-VASc and HAS-BLED scores. High Blood Press Cardiovasc Prev. 2018;25(1):61-64.

22. Michelena HI, Powell BD, Brady PA, Friedman PA, Ezekowitz MD. Gender in atrial fibrillation: ten years later. Gend Med. 2010;7(3): 206-217.

23. Renoux C, Coulombe J, Suissa S. Revisiting sex differences in outcomes in non-valvular atrial fibrillation: a population-based cohort study. Eur Heart J. 2017;38(19):1473-1479.

24. Camm AJ, Savelieva I. Female gender as a risk factor for stroke associated with atrial fibrillation. Eur Heart J. 2017;38(19):1480-1484.
25. Volgman AS, Manankil MF, Mookherjee D, Trohman RG. Women with atrial fibrillation: greater risk, less attention. Gend Med. 2009;6(3): 419-432.

26. Ko D, Rahman F, Schnabel RB, Yin X, Benjamin EJ, Christophersen IE. Atrial fibrillation in women: epidemiology, pathophysiology, presentation, and prognosis. Nat Rev Cardiol. 2016;13(6):321-332.

27. O'Neal WT, Sandesara P, Hammadah M, et al. Gender differences in the risk of adverse outcomes in patients with atrial fibrillation and heart failure with preserved ejection fraction. Am J Cardiol. 2017;119(11):1785-1790.

28. Dzeshka MS, Shantsila A, Shantsila E, Lip GYH. Atrial fibrillation and hypertension. Hypertension. 2017;70(5):854-861.

29. Conti A, Alesi A, Trausi F, et al. Hypertension and atrial fibrillation. Crit Pathw Cardiol. 2014;13(4):141-146.

30. Drazner MH. The progression of hypertensive heart disease. Circulation 2011;123(3):327-334

31. Lip GY. Atrial fibrillation in patients with hypertension: trajectories of risk factors in yet another manifestation of hypertensive target organ damage. Hypertension. 2016;68(3):544-545.

32. Thomas KL, Jackson LR, Shrader P, et al. Prevalence, characteristics, and outcomes of valvular heart disease in patients with atrial fibrillation: insights from the ORBIT-AF (Outcomes Registry for Better Informed Treatment for Atrial Fibrillation). J Am Heart Assoc. 2017;6(12):e006475.

33. Tornos P. Valvular heart disease in women. Rev Esp Cardiol. 2006;59(8):832-836.

34. Disease VH. Summary of valvular heart disease. Eur Heart J. 2012:1-2.

35. Ahmed A, Campbell RC. Epidemiology of chronic kidney disease in heart failure. Heart Fail Clin. 2008;4(4):387-399.

36. Bhatti NK, Karimi Galougahi K, Paz Y, et al. Diagnosis and management of cardiovascular disease in advanced and end-stage renal disease. J Am Heart Assoc. 2016;5(8):e003648.

37. Gheorghiade M, Sopko G, de Luca L, et al. Navigating the crossroads of coronary artery disease and heart failure. Circulation. 2006;114(11) 1202-1213.
International Journal of General Medicine

\section{Publish your work in this journal}

The International Journal of General Medicine is an international peer-reviewed open-access journal that focuses on general and internal medicine, pathogenesis, epidemiology, diagnosis, monitoring and treatment protocols. The journal is characterized by the rapid reporting of reviews, original research and clinical studies across all disease areas.

\section{Dovepress}

The manuscript management system is completely online and includes a very quick and fair peer-review system, which is all easy to use. Visit http://www.dovepress.com/testimonials.php to read real quotes from published authors. 